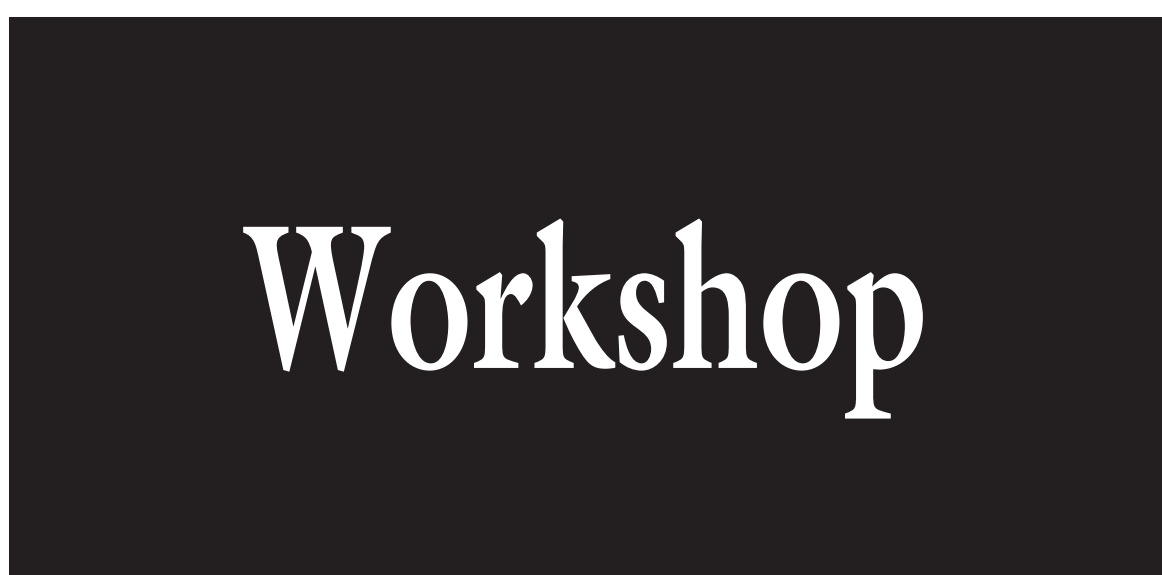

\section{The Scholarship of a University Garden Director}

\author{
Mary Lewnes Albrecht ${ }^{1,2}$
}

ADDITIONAL INDEX WORDS. public horticulture, faculty evaluation, engagement

Summary. More universities are developing on-campus horticultural, landscape, or botanical gardens. Campus gardens often evolved from the life's work of one or a few dedicated faculty members during the second half of the 20th century. Today's faculty face different demands on their time, with pressure to conduct research funded through grants and contracts and resulting in peer-reviewed journal articles. The role of faculty as university garden directors does not blend well with the scholarship associated with fundamental research. The work of a university garden director does blend well within the context of Boyer's model of scholarship that has been modified by others not only to accept the scholarship of research, but also the scholarship of integration, teaching, and engagement as equally valued forms of scholarship.

$\mathrm{F}$ aculty members serve many different roles over the course of their professional career. Most frequently, we think in terms of their roles as teachers and researchers. Teaching may occur in the classroom for credit, or non-credit programs, such as extension programming, or outside the classroom in servicelearning activities, internships, and cocurricular activities (e.g., advisor to clubs, competition teams, fraternities, sororities, and honor societies). Research is well understood to be laboratory or field-oriented, fundamental or applied, integrative or narrowly defined. Service is typically defined as work, outside the teaching, research, or extension programs, that relies upon the individual's professional

\footnotetext{
Department of Plant Sciences, College of Agricultural Sciences and Natural Resources, University of Tennessee, 126 Morgan Hall, Knoxville, TN 37996-4500

${ }^{1}$ Professor and Associate Dean for Academic Programs. ${ }^{2}$ Corresponding author. E-mail: mlalbrecht@utk.edu.
}

knowledge, such as service to professional societies and government agencies at state or federal levels, service to the community on advisory boards, or other pro bono consultative activities (Schnaubelt and Statham, 2007). While some institutions include service to the department, college, or university on curriculum committees, faculty senates, graduate councils, judicial boards, and other activities related to the functioning of the university's programs (Schnaubelt and Statham, 2007), Paulsen and Feldman (1995) identify this type of work as academic citizenship. Garden directors may be engaged in teaching, research, outreach, service, and citizenship; however, the nature of their scholarship usually differs from the to horticulture faculty. Rather, the scholarship may very well be qualitative and is often based on case study. The objective of this article is to discuss the role of faculty as garden typical quantitative research common directors, their scholarly contributions, and their contribution to the advancement of horticulture and the advancement of the institution for which they work.

\section{Responsibilities of a university garden director}

Depending on the needs of the institution, the role of the garden director can vary; however, it will include some or all of the following.

INTEGRATING THE GARDENS INTO THE EDUCATIONAL PROGRAM OF THE UNIVERSITY. University gardens typically are integrated into courses offered in horticulture, soils, entomology, plant pathology, and agricultural/ biosystems engineering. There are opportunities to integrate them into art, journalism and electronic media, biology, botany, ecology, public relations, theatre, and wildlife biology/ science courses. University gardens may be used solely for identification and specimen collections; however, they are more richly integrated when used in service-learning, experientiallearning, and other opportunities.

INTEGRATING INTO THE RESEARCH MISSION OF THE UNIVERSITY. University gardens provide a valuable resource for research related to plant germplasm preservation and conservation, taxonomic studies, plant evaluation, sustainable landscape practices, people-plant interaction, science and natural resources education, and technology transfer work.

Providing OVERSIGHT TO OUTREACH ACTIVITIES AFFECTING STAKEHOLDERS. Programming may include students (kindergarten through grade 16), the green industry (landscapers, nursery and greenhouse growers, and turfgrass managers) and the public (Master Gardeners, garden clubs, professional photographers, the arts, church and civic groups, and alumni).

BUDGET MANAGEMENT AND FUNDING. Higher education is undergoing a paradigm switch from statefunded universities to the privatization of universities. This transition has further accelerated with the recession that started in Dec. 2007 (Isidore, 2008). University garden directors will likely become more engaged in writing grants and pursuing contracts, donations of gifts-in-kind, and financial gifts from foundations and individuals. 


\section{Evaluating the university garden director}

Typically, most faculty evaluation processes are based on annual planning and goal setting, integrated with faculty reporting accomplishments and contributions, and then explaining how these relate to the annual plan and goals established for the evaluation period.

A critical component of the annual report is the discussion of the faculty member's scholarship. Faculty scholarship takes various forms: 1) creating new knowledge: the scholarship of discovery; 2) connecting knowledge to other knowledge: the scholarship of integration and scholarship of teaching; and 3) making specialized knowledge publicly accessible and usable: the scholarship of application, also labeled the scholarship of engagement (Boyer, 1990; Rice, 2002; Schnaubelt and Statham, $2007)$. Boyer asserts that "the work of the scholars also means stepping back from one's investigation, looking for connections, building bridges between theory and practice, and communicating one's knowledge effectively to students" (1990). The work of a garden director exemplifies the work of a scholar.

According to Boyer, "It flies in the face of all experience to expect a professor to engage in the same type of performance across an entire career, without a change of pace" (1990). The arena of creating new knowledge is where many faculty start their careers and where many think we should all be for our entire careers. For some, the creation of new knowledge is the creation of knowledge used only by other researchers; this is generally considered basic or fundamental research and results in peer-reviewed journal articles.

Others will connect knowledge to other knowledge. This is where applied research lies and where much of the work of many horticulture faculty, including those engaged in extension and teaching, lies. These colleagues take basic research, integrate it with other knowledge, and connect it to practice. Integration is common in other disciplines such as engineering, education, communications, social work, and business.

Still other faculty make specialized knowledge publicly accessible and usable. Those engaged with the scholarship of application or engagement are found in medicine, psychology,

Table 1. Scholarship for faculty serving as a university gardens director.

\begin{tabular}{|c|c|c|}
\hline Type of scholarship & Definition & Example of work \\
\hline Discovery & $\begin{array}{l}\text { The search for new knowledge or new } \\
\text { ways of understanding (Boyer, 1990) }\end{array}$ & $\begin{array}{l}\text { Participation with North American Plant } \\
\text { Collection Consortium } \\
\text { Species reference collections } \\
\text { Germplasm conservation and study } \\
\text { Taxonomic studies } \\
\text { Plant breeding and genetics } \\
\text { Human-plant interaction }\end{array}$ \\
\hline Teaching & $\begin{array}{l}\text { The transformation of knowledge through } \\
\text { discipline specific pedagogy (Rice, 2002) }\end{array}$ & $\begin{array}{l}\text { Horticulture courses } \\
\text { Landscape design and construction } \\
\text { Plant identification and utilization } \\
\text { Turf management } \\
\text { Horticulture internships } \\
\text { Gardens management } \\
\text { Plant propagation } \\
\text { Plant production } \\
\text { Volunteer program trainer and manager } \\
\text { Science education in collaboration with } \\
\text { elementary or secondary education programs } \\
\text { Children's reading programs in collaboration } \\
\text { with university or public library } \\
\text { Public relations internships }\end{array}$ \\
\hline
\end{tabular}


law, audiology, education, architecture, agriculture, and many other programs.

The activity or impact of the scholarship of integration, teaching, and engagement is more than peerreviewed journals. It includes books, wikis [e.g., eXtension (eXtension, 2009)], end-user publications (e.g., trade and garden magazines, websites, etc.), invited presentations, and other measures of reputation.

Rachel Carson's Silent Spring (1962) is an excellent example of the scholarship of integration that was an impactful work and gave knowledge to the community. Stephen E. Ambrose's Band of Brothers (2001) is an example of scholarship of discovery and integration that was a case study of a defined group of soldiers based on interviews, letters, and military records that described their experience and presented it in a way that others could relate to the human experience. Both are seminal works that are not peer-reviewed journal articles, yet demonstrate a high level of scholarship. The key to them being acceptable scholarship is that they have been peer validated.

A garden director's work is peer validated as well. However, it becomes incumbent upon faculty, who serve in this role, to demonstrate how they have communicated their work and how it has been validated as scholarship (Weiser and Houglum, 1998). Examples of validation measures are adoption of materials in programs of their peers or invitation to participate in workshops and seminars. Communication of the work may be through radio and television, websites, garden magazines, industry newsletters and magazines, or newspaper articles.

When evaluating the work of the faculty member who serves as a university garden director, we need to identify the connections made and to assess the impact on the communities served. Identifying the communities and the connections is a relatively easy thing to do; communities served are other researchers, teachers, extension personnel, consultants, industry, endusers (e.g., gardeners, children, college students), and state and federal agencies. The connections made are the various programs reaching the aforementioned communities. Impact will be measured by hits on websites, circulation of stories in mass media, adoption of practices, changed behavior, and lives changed. Table 1 presents the way the work of faculty who serve in the role as university garden director relates to scholarship.

The challenge of accepting the work of university garden directors as scholarship may be easier with deans and provosts than it may be departmental faculty and college committees who review tenure and promotion packages. According to O'Meara (2005) "campuses that initiated policy reforms to encourage multiple forms of scholarship were significantly more likely than their counterparts to report that teaching scholarship and engagement counted more for faculty evaluation, to report a broader set of criteria used to assess scholarship, and report a higher percentage of tenure and promotion cases that emphasized their work in these areas." It becomes critical for leaders to accept multiple roles for faculty over the course of their career. Schnaubelt's and Statham's (2007) work showed that faculty review committees tend to be the roadblock to accepting multiple and/or different faculty roles.

Garden directors can make a significant impact on advancing horticulture and enhancing the reputation of departments and universities through their work. Their work is measured not just in refereed journal publications. Rather, it is measured also by writing to show the connections made and the communities served through the university garden in a wide array of outlets, including garden magazines, newspapers, the Internet, radio, and television. Therefore, it becomes incumbent upon administrators to be engaged in a broad discussion over what constitutes excellence in the academy, taking into account the mission of the institution and the needs of undergraduate and graduate education and knowledge discovery and transfer through outreach.

\section{Literature cited}

Ambrose, S.E. 2001. Band of brothers: E Company, 506th Regiment, 101st Airborne from Normandy to Hitler's Eagle's Nest. 3rd ed. Simon \& Schuster, New York.

Boyer, E.L. 1990. Scholarship reconsidered: Priorities of the professoriate. JosseyBass, San Francisco.

Carson, R. 1962. Silent spring. Houghton Mifflin, Boston.

eXtension. 2009. National eXtension initiative. 13 Nov. 2009. <http://about. extension.org/>.

Isidore, I. 2008. It's official: Recession since December '07. 2 Oct. 2009. <http://money.cnn.com/2008/12/ $01 /$ news/economy/recession/index. htm>.

O'Meara, K.A. 2005. Encouraging multiple forms of scholarship in faculty rewards systems. Res. Higher Educ. 46: 479-510.

Paulsen, M.B. and K.A. Feldman. 1995. Toward a reconceptualization of scholarship: A human action system with functional imperatives. J. Higher Educ. 66: 615-640.

Rice, E.R. 2002. Beyond scholarship reconsidered: Toward an enlarged vision of the scholarly work of faculty members. N. Dir. Teach. Learn. 90:7-17.

Schnaubelt, T. and A. Statham. 2007. Faculty perceptions of service as a mode of scholarship. Michigan J. Community Service Learning 14(1):18-31.

Weiser, C.J. and L. Houglum. 1998. Scholarship unbound for the 21st Century. J. Ext. 36(4). 17 July 2009. <http:// www.joe.org/joe/1998august/al .php>. 